\title{
Morphological Changes in the Seminal Receptacle During Ovarian Development in the Speckled Swimming Crab Arenaeus cribrarius
}

\author{
FERNANDO JOSE ZARA ${ }^{1, *}$, GERSON RODRIGUES RAGGI PEREIRA ${ }^{2}$, AND \\ BRUNO SAMPAIO SANT'ANNA ${ }^{3}$ \\ ${ }^{1}$ Univ. Estadual Paulista (UNESP), FCAV, Invertebrate Morphology Laboratory (IML), Departamento \\ de Biologia Aplicada, Aquaculture Center (CAUNESP) and Instituto Avançado de Estudos do Mar \\ (IEAMar-UNESP), Via de Acesso Prof. Paulo Donato Castellane, s/n, Jaboticabal, 14884-900, São \\ Paulo, Brazil; ${ }^{2}$ Univ. Estadual Paulista (UNESP), Campus do Litoral Paulista, Praça Infante Don \\ Henrique s/n, São Vicente, 11330-900, São Paulo, Brazil; and ${ }^{3}$ Universidade Federal do Amazonas \\ (UFAM), Instituto de Ciências Exatas e Tecnologia (ICET), Rua Nossa Senhora do Rosário, $n^{\circ} 3863$, \\ 69103-128 Itacoatiara, Amazonas, Brazil
}

\begin{abstract}
To understand sperm plug dissolution and spermatophore dehiscence in Portunidae, histological and ultrastructural changes in the seminal receptacle (SR) of Arenaeus cribrarius were investigated during ovarian development. In juvenile females the SR was filled with acid polysaccharides and the dorsal epithelium was stratified. Mated females with rudimentary ovaries showed a large SR filled by a glycoprotein sperm plug. This plug was present until the developing-ovary stage, when spermatophore dehiscence and intense holocrine secretions in the dorsal dense layer occurred. The plug was absent after the intermediate stage, and the SR became flaccid. The secretion produced moved the spermatophores into the ventral region. The modified dorsal epithelium in the transition between the dorsal and ventral regions released acid polysaccharides, which were found among the sperm, by exocytosis. The morphological changes of the SR in A. cribrarius, including the presence of the sperm plug, followed the macroscopic pattern observed in other members of Portunidae, such as blue crabs. However, in this species dissolution of the sperm plug was synchronized with ovarian
\end{abstract}

Received 17 September 2013; accepted 5 May 2014.

* To whom correspondence should be addressed. E-mail: fjzara@fcav. unesp.br

Abbreviations: SR, seminal receptacle; Developmental Stages: DE, developing; INT, intermediate; JUV, juvenile; MAT, mature; OV, ovigerous; RUD, rudimentary. development and occurred simultaneously with spermatophore dehiscence, showing the evolutionary relationship of the seminal receptacle and the female reproductive system to the storage of spermatophores and spermatozoa.

\section{Introduction}

Eubrachyuran females have a pair of seminal receptacles (SR) of ecto-mesodermal origin, which store spermatophores or spermatozoa after mating (Diesel, 1991; Guinot and Quenette, 2005; McLay and López Greco, 2011). The dorsal-mesodermal region of the SR is connected to the ovary by the oviduct, while the ventral-ectodermal region of the SR is cuticle-lined and connected to the vagina (McLay and López Greco, 2011). In Portunidae, as in other members of Eubrachyura, the vagina opens into the vulva, located in the sixth thoracic sternite (Pyle and Cronin, 1950; Johnson, 1980; Guinot et al., 2013).

Diesel (1991) recognized two types of SR. The dorsal type has the oviduct opening in a relatively dorsal position, with the vagina lying ventrally far from the oviduct. In the ventral type, both the oviduct and vagina opening are close to each other and are positioned ventrally. Recently, a third, intermediate type, was recognized, with the oviduct opening into the SR between the dorso-ventral extremes (McLay and López Greco, 2011; Gonzáles-Pisani et al., 2012; Guinot et al., 2013). Most members of Portunidae possess the dorsaltype SR; the only known exception is the intermediate type 
found in Portunus hawaiiensis (Herbst, 1783) (Ryan, 1967, as Portunus sanguinolentus, Diesel, 1991; McLay and López Greco, 2011).

Viewed under light microscopy, the mesoderm-derived epithelium of the dorsal region varies from squamous and highly stratified - as observed in Majoidea (Beninger et al., 1988, 1993; Diesel, 1989; Sainte-Marie and Sainte-Marie, 1998; Rotllant et al., 2007; Gonzáles-Pisani et al., 2012) and Portunoidea (Ryan, 1967; Hartnoll, 1968; Johnson, 1980) - to cubic-columnar, ranging from one to three strata in Grapsoidea (López Greco et al., 1999), Ocypodoidea (Sant'Anna et al., 2007; López Greco et al., 2009; Lautenschlager et al., 2010; Souza et al., 2013), and Pinnotheridae (Becker et al., 2011). The ectoderm-derived epithelium of the ventral region is cuticle-lined and may be termed the fertilization chamber (Beninger et al., 1988; Diesel, 1989; López Greco et al., 1999; Sant'Anna et al., 2007; Souza et al., 2013). In the transition zone between the dorsal and ventral regions, a dorsal modified epithelium with columnar cells was found in Callinectes sapidus Rathbun, 1896 (Johnson, 1980) and P. hawaiiensis (Ryan, 1967, as $P$. sanguinolentus). This epithelium differs from the "velum" found in Inachus phalagium (Fabricius, 1775) and Libinia spinosa Milne Edwards, 1834 (Diesel, 1989; GonzálezPisani et al., 2012), which has different functions according to the SR morphology and degree of filling.

During mating in Portunidae, a large amount of seminal fluid is transferred to the SR, causing the organ to enlarge (Ryan, 1967; Johnson, 1980; Zara et al., 2012). These secretions form the sperm plug (Hartnoll, 1968, 1969) that prevents subsequent copulation (Jivoff, 1997a; Hines et al., 2003; Wolcott et al., 2005). This plug disappears after a certain time and the SR becomes flaccid, as observed in Portunus pelagicus (Linnaeus, 1758) (Bawab and El-Sherief, 1988), P. hawaiiensis (Ryan, 1967, as P. sanguinolentus), C. sapidus (Johnson, 1980; Hines et al., 2003; Wolcott et al., 2005), Arenaeus cribrarius (Lamarck, 1818) (Pinheiro and Fransozo, 2002), and Ovalipes ocellatus (Herbst, 1799) (Hinsch, 1986). The reduction of the SR is not synchronized with the seasons (Bawab and El-Sherief, 1988; Pinheiro and Fransozo, 2002; Hines et al., 2003), and in $C$. sapidus the reduction of the SR is clearly associated with ovarian development (Wolcott et al., 2005). Thus, further investigations are needed to elucidate whether this pattern of reduction of the SR, including spermatophore dehiscence - that is, rupture of spermatophore wall and release of spermatozoa - can be considered a general pattern in Portunidae.

In Brazil, members of the family Portunidae are important as part of the by-catch of the shrimp fishery, and also in small-scale fisheries (Pinheiro and Fransozo, 2002; GraçaLopes et al., 2002). The speckled swimming crab A. cribrarius shows continuous reproduction; females with rudimentary ovaries show an enlarged seminal receptacle, and subsequent reductions in the volume of this organ were confirmed macroscopically (Pinheiro and Fransozo, 2002). This morphological change in the SR of A. cribrarius has not been studied under light microscopy, as has the relationship of ovarian development and morphological changes in the SR of other members of Portunidae. Studies using transmission electron microscopy to examine the SR have usually described the sperm ultrastructure. A relatively few studies have examined the ultrastructure of the SR cells, such as in ocypodids (Lautenschlager et al., 2010) and pinnotherids (Becker et al., 2011), or the ultrastructure of the dorsal epithelium (glandular) cells in majoids (Beninger et al., 1993). The present study investigated the histological, histochemical, and ultrastructural changes of the SR of $A$. cribrarius during ovarian development. We hypothesized that a relationship exists between the ovarian cycle and the use of the seminal receptacle contents, showing the evolutionary relationship between the seminal receptacle and the female reproductive system with the presence of spermatophores and spermatozoa, to promote reproductive success in this species.

\section{Materials and Methods}

\section{Animal samples and macroscopic procedures}

The crabs were caught monthly in Santos-São Vicente Bay from March 2007 through February 2010, from a shrimp-fishing boat equipped with a semi-balloon ottertrawl net. The female crabs were transported alive in a plastic box with aerated seawater to the laboratory. The crabs were identified according to Melo (1996) and sorted as to their developmental stage: juvenile (JUV), adult, or ovigerous adult. Each crab was weighed, and the carapace width $(\mathrm{CW})$ was measured between the bases of the lateral spines, using a caliper $(0.05 \mathrm{~mm})$.

To assess the reproductive system, the animals were anesthetized by thermal shock and dissected. Tissues from JUV females were obtained from females held by males in pre-copulatory mating guard, showing an attached triangular abdomen (Pinheiro and Fransozo, 1998, 1999). For the adult females, the ovarian stage was classified macroscopically according to the color and the size of the ovary in proportion to the hepatopancreas. The adult ovarian stages were ranked as rudimentary (RUD), developing (DE), intermediate (INT), mature (MAT), and spent or ovigerous (OV) (adapted from Costa and Negreiros-Fransozo, 1998; Pinheiro and Fransozo, 1998; Zara et al., 2013). In this study, only SRs from OV females showing RUD ovaries, following the criteria adopted by Zara et al. (2013), were used.

The right SRs in each ovarian stage from all collected females were removed and weighed on an analytical balance $(0.0001 \mathrm{~g})$. The left seminal receptacles of at least three crabs in each ovarian stage were used for histological 
and transmission electron microscopy (TEM) analyses. The normality of the SR weight was evaluated by the ShapiroWilk test for each ovarian stage, and the weights of the ovarian stages were compared by the Kruskal-Wallis test complemented by the Dunn test, with a significance level of $P<0.05$ (Sokal and Rohlf, 1995).

\section{Histology and transmission electron microscopy}

The left SRs were fixed in 4\% paraformaldehyde in 0.2 mol $\mathrm{l}^{-1}$ phosphate buffer ( $\mathrm{pH}$ 7.2) for 24-48 $\mathrm{h}$, washed twice for $1 \mathrm{~h}$ with the same buffer, dehydrated in an ascending ethanol series, and embedded in glycol methacrylate resin (Leica historesin kit). The blocks were cut in a Leica RM2245 microtome, and the 5- to 8- $\mu \mathrm{m}$ sections were stained with hematoxylin and eosin (HE) and toluidine blue for general description (Junqueira and Junqueira, 1983, modified according to Sant'Anna et al., 2010).

For histochemistry, the SR sections were stained for proteins using the Xylidine ponceau (Mello and Vidal, 1980) and mercuric-bromophenol blue (Pearse, 1985) techniques. PAS was used for neutral polysaccharides with 1,2-glycol groups, and Alcian blue ( $\mathrm{pH} 1.0$ and 2.5) for acid polysaccharides (Junqueira and Junqueira, 1983). Collagen fibers were revealed with picrosirius red (Direct red 80) (Junqueira and Junqueira, 1983) and collagen III by the silver impregnation method (Gömöri, 1937). The images were obtained in a Leica DM2000 light microscope and digitalized using Leica IM50 software.

For TEM, small fragments from each ovarian stage (1-2 $\mathrm{mm}$ ) obtained from different regions of the SRs were fixed in 3\% glutaraldehyde prepared with filtered seawater in 0.1 mol $1^{-1}$ sodium cacodylate buffer $(\mathrm{pH} 7.3$ ) with $0.2 \%$ picric acid (Mancini and Dolder, 2001). The samples were postfixed using $1 \%$ osmium tetroxide, stained "en bloc" with $1 \%$ uranyl acetate, dehydrated in ethanol (70\%-100\%), and embedded in Epon-Araldite resin. The ultrathin sections were obtained with a Leica UC7 ultramicrotome. The copper grids were contrasted with aqueous $2 \%$ uranyl acetate and $2 \%$ lead citrate. The images were photographed with a Jeol J1010 TEM at $80 \mathrm{kV}$.

\section{Spermatophore dehiscence in seawater}

Spermatophore dehiscence was observed according to Beninger et al. (1993), using light microscopy instead of stereomicroscopy. Spermatophores from the anterior and posterior vas deferens of three mature adult males of $A$. cribrarius were mixed and diluted in $3 \mathrm{ml}$ of seawater. A sample of $100 \mu \mathrm{m}$ of this solution was placed on slides and covered with coverslips. The spermatophores on the slides (minimum 30 in each image) were photographed at intervals of $0,5,10,15,20,25,30,60$, and $90 \mathrm{~min}$, with the software Leica IM50. The percentage of dehiscence was determined for each time interval.

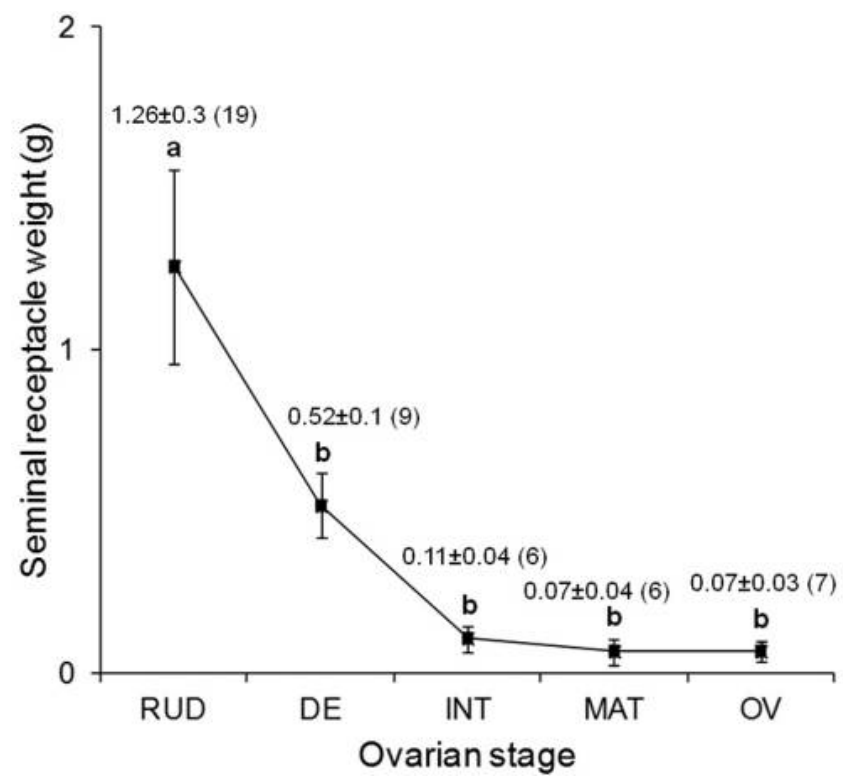

Figure 1. Weight (mean and standard deviation) of the right seminal receptacle of Arenaeus cribrarius in the different ovarian stages: rudimentary (RUD), developing (DE), intermediate (INT), mature (MAT), and ovigerous rudimentary $(\mathrm{OV})$. The number of individuals analyzed in each ovarian stage is shown in parentheses. Means followed by the same lower-case letter did not show significant differences $(P<0.05)$ in the Dunn test.

\section{Results}

Seminal receptacle weight according to stage of ovarian development

In Arenaeus cribrarius the seminal receptacle (SR) weight varied significantly throughout ovarian development (Kruskal-Wallace, $H=40.57 ; P<0.0001$ ). Recently mated females with ovaries in the RUD stage showed the highest weight, and the weight decreased significantly in females in the DE stage (Dunn, $P<0.05$ ). In spite of the trend toward SR weight reduction from the DE to INT stages, the values did not show significant differences (Dunn, $P>0.05$ ). A lack of significant difference was also found between the INT and MAT, and the MAT and OV stages. Thus, the main reduction in SR volume occurred during the initial stages of the ovarian cycle (Fig. 1). The gross anatomy of the SR from juveniles with thin and empty SR to adults, showing the changes in weight during the ovarian cycle, is summarized in Figure 2.

\section{Histology, histochemistry, and ultrastructure of the seminal receptacle}

The SR of A. cribrarius at the JUV stage showed internal folds, a luminal secretion close to the dorsal epithelium, and absence of spermatozoa or spermatophores (Fig. 3A). The receptacle wall was composed of three distinct layers: an 
Juvenile female

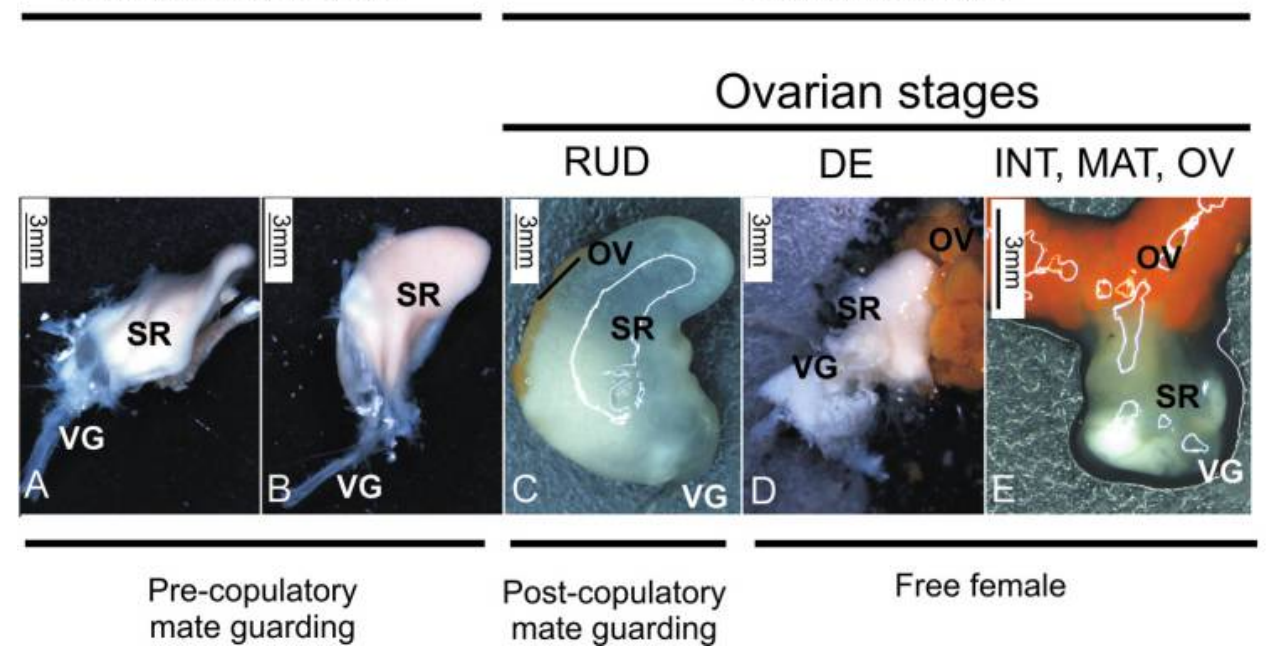

Figure 2. Changes in the seminal receptacle (SR) gross anatomy during the ovarian cycle of females of Arenaeus cribrarius. (A and B) Thin and empty SR of juvenile (JUV) female in dorsal and lateral view, respectively. (C) Enlarged SR of rudimentary (RUD) female just after mating. (D) SR of developing (DE) females. (E) Gross anatomy of SR in the late ovarian stage. This illustration summarizes the morphology found in the intermediate (INT), mature (MAT), and ovigerous (OV) stages. OV = ovary; VG = vagina.

external connective layer; a middle collagen-rich layer, termed the collagen layer; and an internal layer composed of stratified epithelium, termed the dense layer (sensu Johnson, 1980) (Fig. 3B). The connective layer contained fibroblasts and many hemal spaces with hemocytes. The collagen layer contained slightly oriented collagen bundles and smaller hemal spaces (Fig. 3C). In this ovarian stage, the dense layer was a very thick stratified epithelium composed of small cells (Fig. 3B, D). In the apical region of this layer, desquamating cells and an acidophilic luminal secretion were present (Fig. 3D). The ultrastructure of the dense layer cells showed cytoplasmic vesicles with electron-dense and electron-lucent material (Fig. 3E, F). The luminal secretion was homogeneous under TEM, and this secretion near the epithelium was reactive for proteins (Fig. 3G, H), neutral polysaccharides (Fig. 3I), and acid polysaccharides at different pHs (Fig. 3J-M).

The SR of A. cribrarius during the RUD ovarian stage was large, due to the large amount of male secretion forming the internal sperm plug inserted during copulation (Fig. 4A). The spermatophores were distributed mainly around the sperm plug, close to the dense layer in the dorsal region of the SR (Fig. 4A). The connective and collagen layers were thinner, and the hemal spaces were smaller than in the JUV stage (Fig. 4B, C). Both layers showed collagen fibers composed of collagen types I and III stained with the picrosirius red and Gömöri techniques, respectively (Fig. $4 \mathrm{D}, \mathrm{E})$. These collagen types were found in the SR at all ovarian stages. The basal cells of the dense layer showed fewer cytoplasmic vesicles (Fig. 4F). Complete cells in desquamation from the dense layer, many vesicles, and cell debris were found in the lumen close to the epithelium (Fig. $4 \mathrm{G})$. The spermatophore wall was intact inside the sperm plug during this stage (Fig. 4H), and the sperm plug was composed of proteins and neutral polysaccharides (Fig. 4I, J). Acid polysaccharides were not observed in the sperm plug (Fig. 4K). A few spermatophores were also found in the region derived from the ventral ectoderm. No sperm plug was present in the vagina, and only a weakly eosinophilic secretion was detected (Fig. 4L).

The sperm plug was still present in SR lumen during the DE stage. The sperm plug decreased in size and was displaced to the ventral region of the SR (Fig. 5A) compared to the RUD stage (Fig. 4A). The surface of the sperm plug was quite distant from the dorsal dense-layer epithelium (Fig. $5 \mathrm{~A})$. In the dorsal region, the oviduct opening showed the same histological appearance as the dorsal dense-layer epithelium (Fig. 5A). Both the oviduct and the dorsal region of the SR showed folds in the dense layer (Fig. 5B). The apical cells in desquamation found in the dense layer, including these folds, showed large electron-lucent vesicles and were engaged in holocrine secretion (Fig. 5C). Some of these cells were found on the sperm plug surface (Fig. 4D). The cells in desquamation seem to be responsible for the secretions that degrade the sperm plug at the same time that they cause the displacement of the spermatophores to the ventral portion. The large secretory vesicles of these cells showed weak reactivity for proteins and neutral polysaccharides (Fig. 5D, E). During this stage, the spermatophore morphology, as a round mass of spermatozoa, was maintained (Fig. $5 \mathrm{~A}, \mathrm{D})$. However, the spermatophore wall was not seen under light microscopy, and only a few residues of it were 


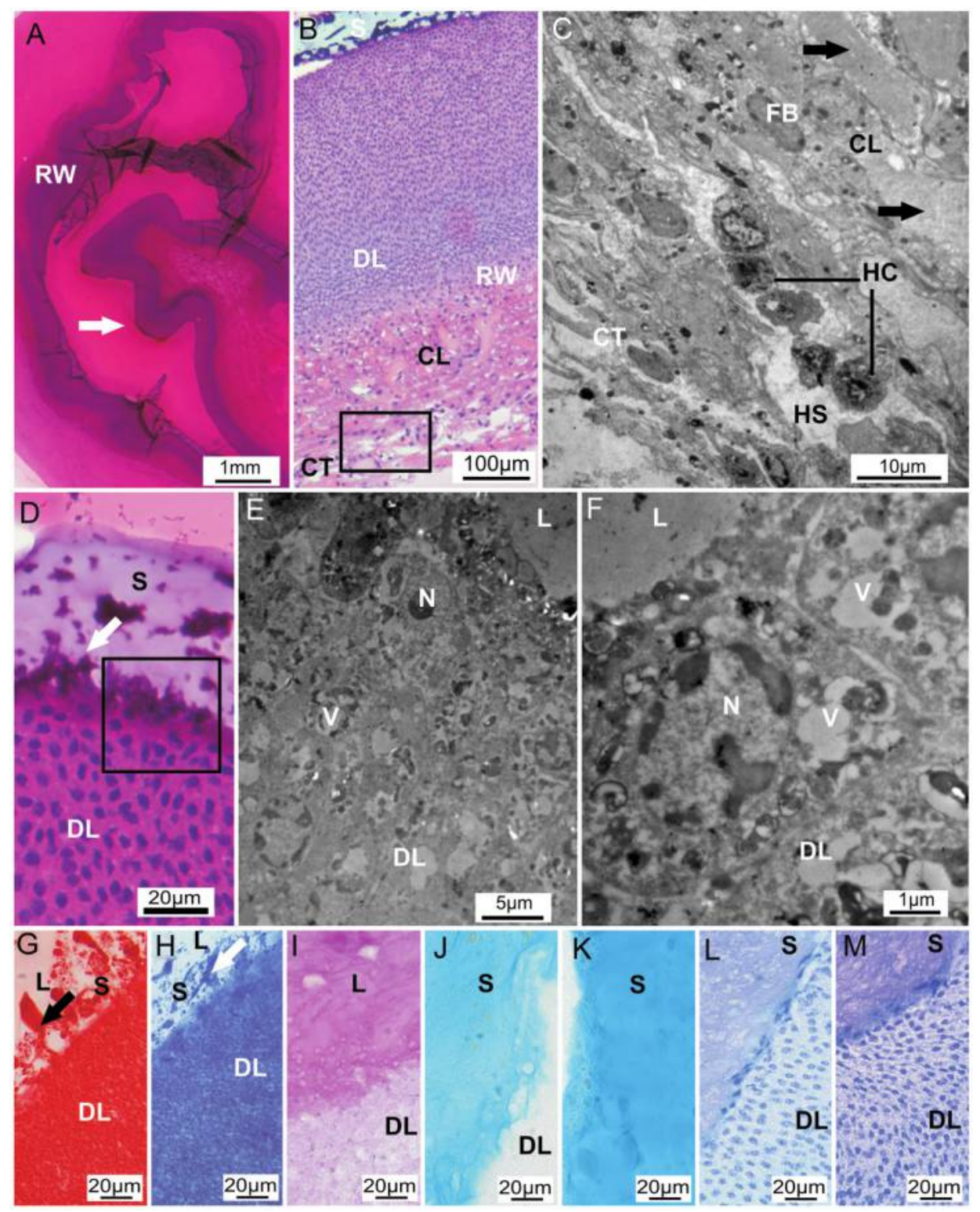

Figure 3. Seminal receptacle (SR) of juvenile (JUV) females. (A) Longitudinal section of SR under a stereomicroscope. The receptacle wall shows some folds in the dorsal region (arrow). Note the absence of spermatophores in the lumen. (B) Dorsal region formed with connective, collagen, and dense layers. Note the basophilic secretion in the lumen close to the epithelium. The rectangular area is shown in panel C. (C) Ultrastructure of connective and collagen layers, depicting fibroblasts, bundles of collagen fibers (arrows), and hemal spaces with hemocytes. (D) Light microscopy image of the dense layer apex showing desquamation cells. Inset indicates the area shown in panels $\mathrm{E}$ and F. (E) General view of the desquamation cells under TEM. (F) Desquamating cell showing vesicles with electron-dense and electron-lucent material. ( $\mathrm{G}$ and $\mathrm{H}$ ) Luminal secretion of the SR with positive reaction for proteins stained with xylidine ponceau and mercuric-bromophenol blue (arrows), respectively. (I) Secretion reactive for neutral polysaccharides stained with PAS. (J and K) Acid polysaccharides detected in SR luminal secretion stained with Alcian blue ( $\mathrm{pH} 1.0$ and 2.5, respectively). ( $\mathrm{L}$ and M) Acid luminal secretion stained with toluidine blue at $\mathrm{pH} 2.5$ and 4. $\mathrm{CL}=$ collagen layer; $\mathrm{CT}=$ connective layer; $\mathrm{DL}=$ dense layer; $\mathrm{FB}=$ fibroblast; $\mathrm{HC}=$ hemocytes; $\mathrm{HS}=$ hemal spaces; $\mathrm{L}=$ lumen; $\mathrm{N}=$ nucleus; $\mathrm{RW}=$ receptacle wall; $\mathrm{S}=$ secretion; $\mathrm{V}=$ vesicle.

noted under TEM (Fig. 5D, F). In the ventral region, free sperm masses were observed (Fig. 5G). Between the dorsal and ventral region of the SR was a modified dorsal epithe- lium (sensu Johnson, 1980). This modified dorsal epithelium, which was also found in the previous stages, was composed of columnar cells possessing long microvilli 

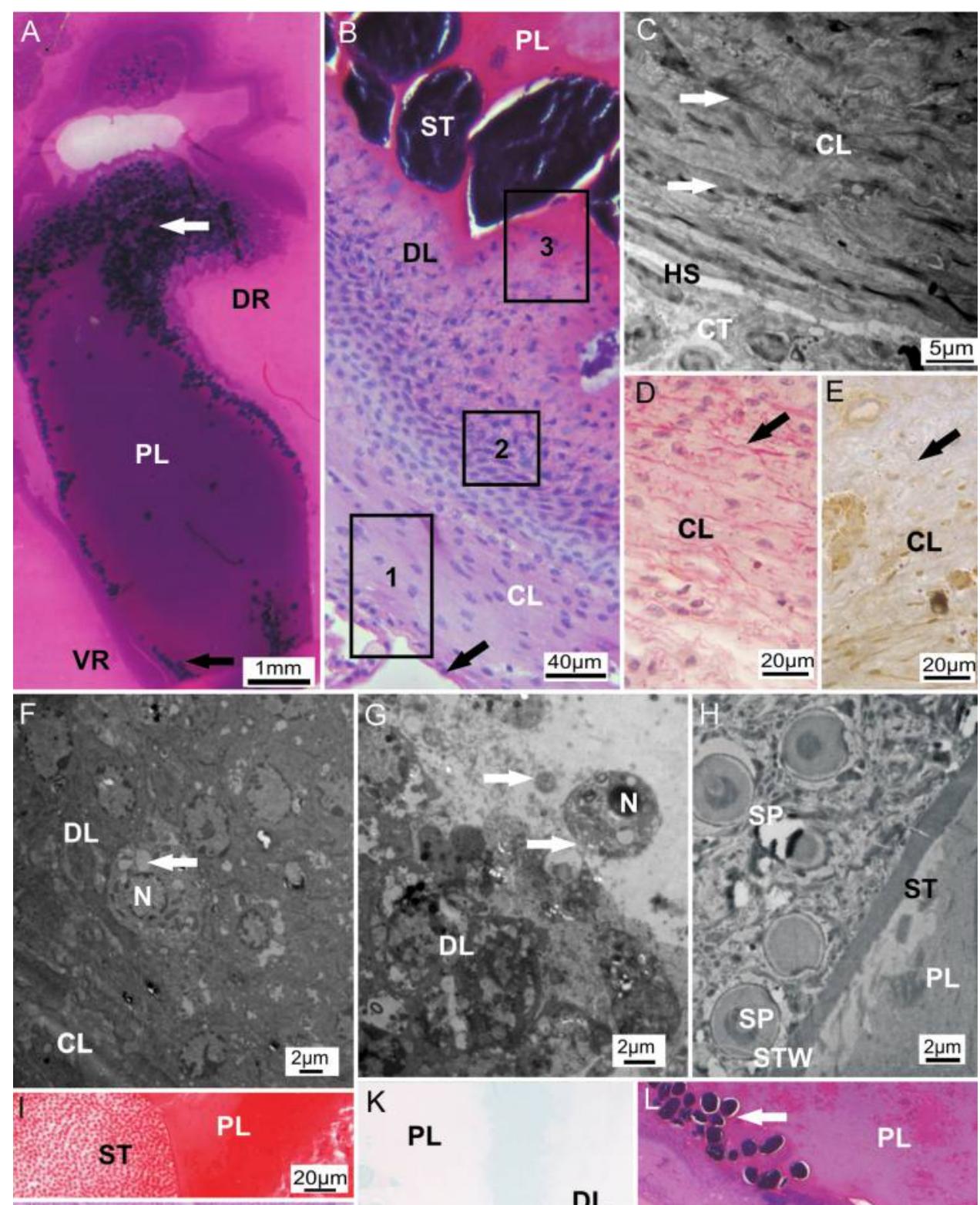

\section{PL}
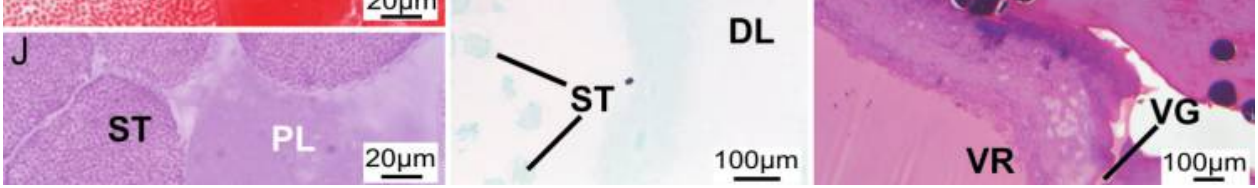

Figure 4. Seminal receptacle (SR) of adult rudimentary (RUD) females. (A) Longitudinal section of dilated SR under a stereomicroscope, filled with the sperm plug and spermatophores (arrow). (B) Detail of the dorsal region of SR showing the distended wall. Note the thin connective layer at this stage, and the small hemal spaces (arrow). The rectangular areas numbered 1, 2, and 3 are shown in panels $\mathrm{C}, \mathrm{F}$, and $\mathrm{G}$, respectively. (C) Ultrastructure of the thin connective and the collagen layers showing reduced hemal spaces and oriented collagen fibers (arrows). (D and E) Collagen I and III (arrows) stained with picrosirius red and Gömöri techniques. (F) Ultrastructure of basal cells in the dense layer epithelium, showing few vesicles in the cytoplasm (arrow). (G) Apex of dense layer, showing complete cells released among cell debris (arrows). (H) Spermatophore with intact wall among the sperm plug. (I and J) Sperm plug positive for protein and neutral polysaccharides, stained with xylidine ponceau and PAS, respectively. $(\mathrm{K})$ Absence of acid polysaccharides in the sperm plug. Note that the spermatophores and secretion close to the dense layer were stained with Alcian blue (pH 2.5). (L) Spermatophores in the ventral region (arrow). Note that no sperm plug is present in the vagina and only a weak eosinophilic secretion is observed. $\mathrm{CL}=$ collagen layer; $\mathrm{CT}=$ connective layer; $\mathrm{DL}=$ dense layer; $\mathrm{DR}=$ dorsal region; $\mathrm{HS}=$ hemal space; $\mathrm{N}=$ nucleus; $\mathrm{PL}=$ sperm plug; $\mathrm{SP}=$ spermatozoa; $\mathrm{ST}=$ spermatophores; $\mathrm{STW}=$ spermatophore wall; $\mathrm{VR}=$ ventral region; $\mathrm{VG}=$ vagina. 

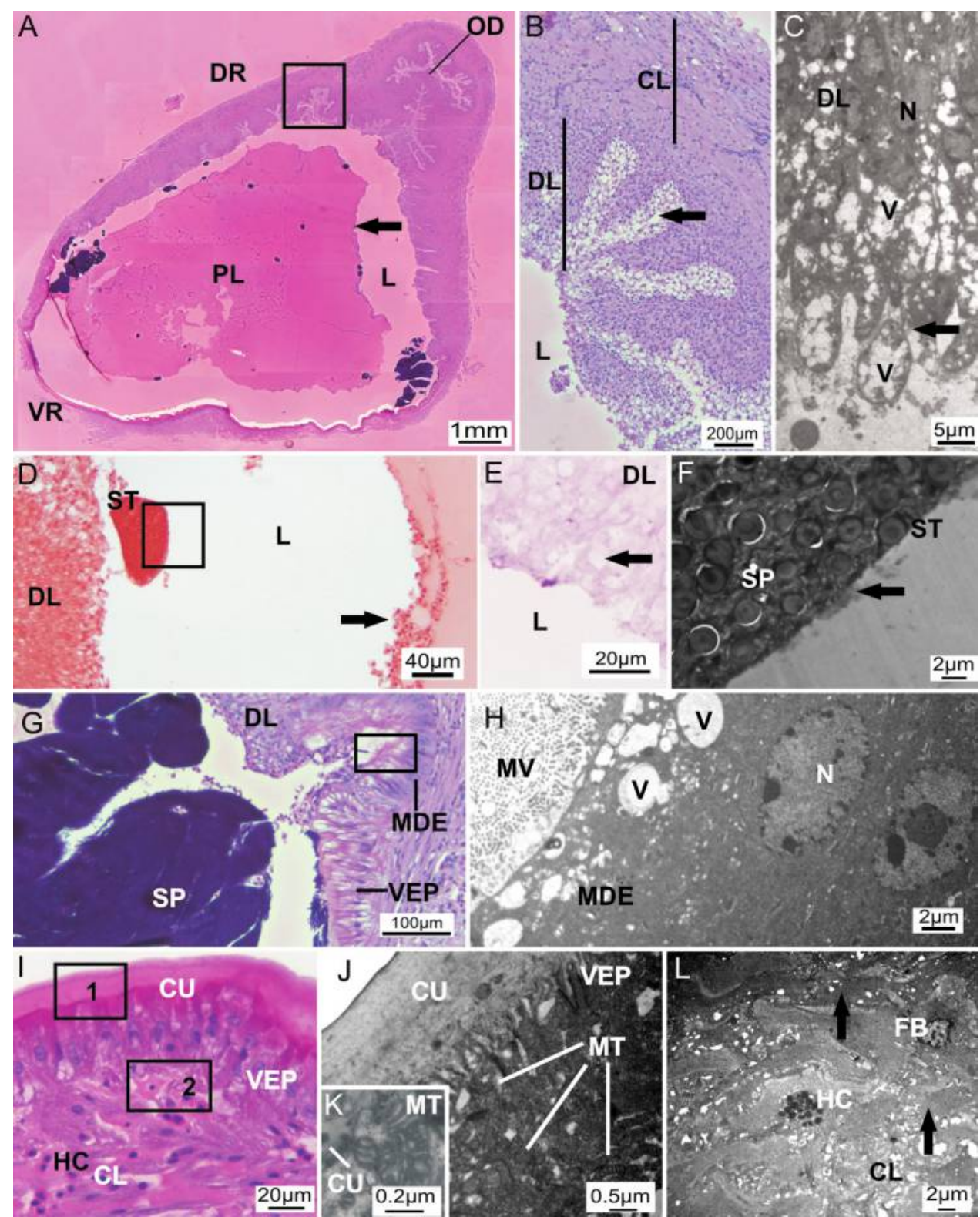

Figure 5. Seminal receptacle (SR) in developing (DE) stage. (A) Montage pictures from a longitudinal section under light microscopy. The SR shows a softened, smaller sperm plug distant from the dorsal epithelium (arrow). The dense layer in the dorsal region shows folds, also observed in the oviduct opening. The rectangular area is shown in panels B and C. (B) Folds in the dense layer lying on the collagenous layer. (C) Ultrastructure of the desquamating cells of the dense layer, depicting several large vesicles. (D) Dense layer stained with xylidine ponceau. Note the spermatophore without a wall and some cells reaching and entering the sperm plug (arrow), positive for proteins. Inset is shown in panel G. (E) Weak reaction to neutral polysaccharides in the vesicles (arrow) of the dense layer stained with PAS. (F) Fragments of the spermatophore wall around the sperm mass (arrow). (G) Modified epithelium in the transition between the ventral and dorsal regions of the receptacle. The rectangular area is shown in panel H. $(\mathrm{H})$ Higher magnification of modified epithelium, showing secretory vesicles in the apex. Note two nuclei and thin microvilli. (I) Simple epithelium of the ventral region, lined with cuticle lying on the thin collagen layer. Rectangles 1 and 2 are shown in panels $\mathrm{K}$ and $\mathrm{L}$, respectively. $(\mathrm{K})$ Cuticle and apical cytoplasm filled with numerous mitochondria. (L) Collagen layer in the ventral region, showing fibroblasts, hemocytes, and collagen bundles (arrow). $\mathrm{CL}=$ collagen layer; $\mathrm{CU}=$ cuticle; $\mathrm{DL}=$ dense layer; $\mathrm{DR}=$ dorsal region; $\mathrm{FB}=$ fibroblast, $\mathrm{HC}=$ hemocytes; $\mathrm{L}=$ lumen; $\mathrm{MV}=$ microvilli; $\mathrm{MDE}=$ modified epithelium of the dorsal region; $\mathrm{MT}=$ mitochondria; $\mathrm{N}=$ nucleus; $\mathrm{OD}=$ oviduct; $\mathrm{PL}=$ sperm plug; $\mathrm{SP}=$ spermatozoa; $\mathrm{ST}=$ spermatophores; $\mathrm{V}=$ vesicles; $\mathrm{VEP}=$ ventral epithelium; $\mathrm{VR}=$ ventral region. 
(Fig. 5G). The cells contained one or two nuclei and basophilic cytoplasm (Fig. 5G), with some secretory vesicles in the apical cytoplasm (Fig. 5H). The ventral region of the SR was ectoderm-derived, composed of cells lined with cuticle. These cells were arranged in a simple cubic epithelium lying on the fibrous collagen layer (Fig. 5I). The apical cytoplasm was filled with many mitochondria just below the thick cuticle (Fig. 5J, K). The collagen layer was thinner than in the dorsal region, showing fibroblasts and some hemocytes among the collagen bundles (Fig. 5L).

The SRs of A. cribrarius from females in the INT, MAT, and OV stages were similar under light and transmission electron microscopy. The sperm plug was absent, and a free mass of spermatozoa was concentrated in the ventral region of the SR (Fig. 6A). The mesoderm-derived dorsal region moved close to and became continuous with the oviduct. The main change was the extensive reduction of the dense layer. This reduction was identified qualitatively by the test for collagen, showing that the connective layers were still thick, while the dense layer was thinner than in previous stages (Fig. 6B, C). Among the hemal spaces were structured vessels and many hemocytes (Fig. 6D). The cells of the dense layer showed a similar ultrastructure to those found in RUD females, with condensed peripheral heterochromatin in the nucleus and several vesicles in the cytoplasm (Fig. 6E, F). These cells seemed to lose their adhesion during desquamation, and in the epithelium apex the cells were attached to each other by desmosomes at a few points (Fig. 6F). The modified dorsal epithelium showed the same characteristics as in the previous ovarian stages (Fig. 6G). The apex of these cells was reactive for acid polysaccharides (Fig. $6 \mathrm{H}$ ), and under TEM showed vesicles that were released by exocytosis among the microvilli (Fig. 6I, J). On the free edge of these cells were long microvilli with an actin cytoskeleton (Fig. 6J). The basophilic cytoplasm showed characteristics of protein-synthesizing cells, with rough endoplasmic reticulum and a typical Golgi complex (Fig. 6K, L). The ventral region of SR was filled with free sperm (Fig. 6M, N). The cuticle-lined ventral epithelium was similar to that in the previous stage, with many mitochondria (Fig. 60).

In the OV stage, one of the three females used was collected immediately during ovulation, and it was possible to detect oocytes passing through the SR. The ventral region of the SR became slightly eccentric to the oviduct-vagina axis (Fig. 7A). More than one oocyte entered the dorsal region of the SR (Fig. 7B, C), and the oviduct-SR transition was marked because the connective layer of the ovary is thinner than the collagen layer of the dorsal region of the SR (Fig. 7B). The dorsal region of the SR was continuous with the oviduct, showing a thin dense layer, while the collagen layer was thick, as in the previous stage (Fig. 7B, C). The cells of the dense layer showed ultrastructural features similar to those seen in the INT and MAT stages (Fig. 7D).
Although the spermatozoa were concentrated in the ventral region, some spermatozoa were seen above the dorsal modified epithelium, in contact with the oocytes in this region (Fig. 7E). The vagina was continuous with the ventral region of the SR and showed cuticle-lined epithelial cells similar to those in the ventral region. The vagina epithelium was lying on the collagen layer (Fig. 7F, G).

\section{Dehiscence of spermatophores}

The spermatophores taken from the male posterior vas deferens did not show dehiscence during 90 min of contact with seawater. Less than $1 \%$ of the spermatophores from the anterior vas deferens underwent dehiscence within $90 \mathrm{~min}$.

\section{Discussion}

The seminal receptacle (SR) of Arenaeus cribrarius is classified as the dorsal type, following the pattern previously found for Portunidae (Diesel, 1991; McLay and Lopéz Greco, 2011). This anatomy is maintained during the entire ovarian cycle, although the weight and morphology vary. After mating, the SRs of RUD females were completely filled with the internal sperm plug and spermatozoa packed in spermatophores. This internal sperm plug is different from that described for a recently mated cancrid crab, Metacarcinus edwarsii (Bell, 1835), in which the sperm plug is found only in the vaginal channel but is not visible externally (Pardo et al., 2014), and from the external sperm plug that bulges out of the vulva (Hartnoll, 1969). Pinheiro and Fransozo (2002) observed that the internal sperm plug of A. cribrarius persists for a long time in females with immature ovaries, classified here as ovarian stage RUD. In Callinectes sapidus the sperm plug disappears within 3 weeks after mating (Johnson, 1980; Wolcott et al., 2005). The sperm plug in the A. cribrarius SR was presumed to last for about 1 month (Pinheiro and Fransozo, 2002). This study failed to determine the precise time of dissolution of the sperm plug. Nevertheless, in A. cribrarius complete dissolution was synchronized with ovarian development, occurring in intermediate or mature ovaries, as recorded for C. sapidus (Wolcott et al., 2005). In Callinectes danae Smith, 1869 , the DE oocytes increase in size and begin to store yolk granules (Zara et al., 2013). Thus, the transfer and dissolution of the sperm plug are necessary to start ovarian development, as proposed for $C$. sapidus (Hines, 1982; Wolcott et al., 2005) and C. danae (Zara et al., 2012). According to Hines (1982), the limitation of the space reserved in the cephalothorax for ovarian development makes it necessary for the SR to regress, which also occurs in A. cribrarius and some cancrids and varunids (Jensen et al., 1996; Lopéz Greco et al., 1999; Wolcott et al., 2005) and in other portunids (Spalding, 1942; Ryan, 1967; Bawab and El-Sherief, 1988).

The internal glycoprotein sperm plug in A. cribrarius is 

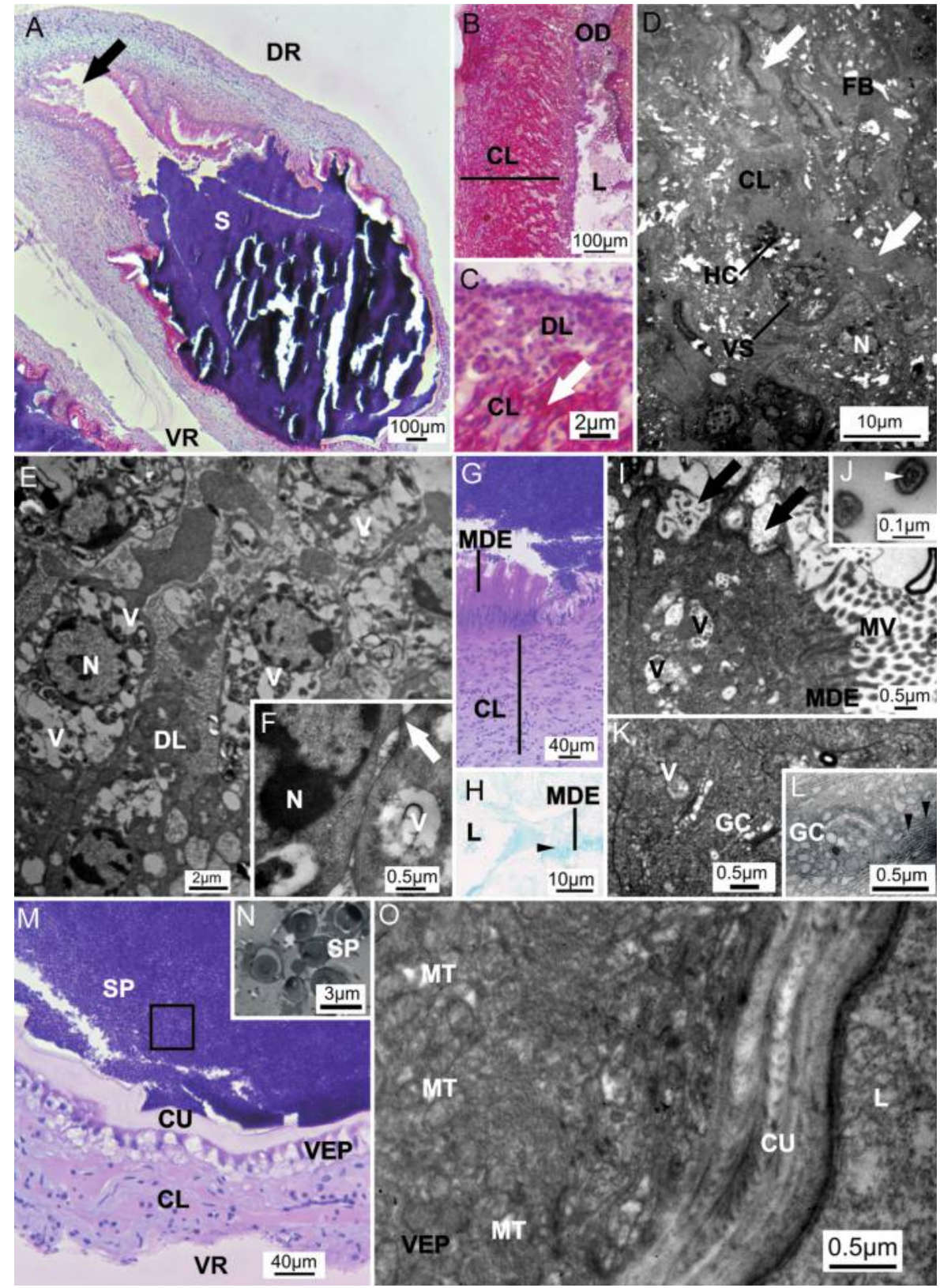

Figure 6. Seminal receptacle (SR) of intermediate (INT) and mature (MAT) stages. (A) Longitudinal section of SR in INT stage. The dorsal region of SR is continuous with the oviduct (arrow). The ventral region is filled with free spermatozoa. (B) Oviduct region continuous with the SR dorsal region. Note the thick collagen layer. (C) Reduced dense layer in the dorsal region and collagen fibers stained with the picrosirius technique. (D) Ultrastructure of the collagen layer, showing collagen fibers, vessels, and hemocytes. (E) Ultrastructure of dense-layer cells, with large numbers of vesicles, similar to the RUD stage. (F) Detail of loose cellular adhesion between dense-layer cells. (G) Modified dorsal epithelium, with basophilic cytoplasm lying on the collagen layer. $(\mathrm{H})$ Acid polysaccharides in the outer edge of the modified dorsal epithelium (arrowhead) and lumen, stained with Alcian blue. (I) Modified dorsal epithelium, releasing its contents by exocytosis between microvilli. (J) Microvillus in transverse section, showing actin filaments. (K and L) General appearance and detail of the cytoplasm of the modified dorsal cell filled with rough endoplasmic reticulum (arrowhead) and Golgi complex. (M) Ventral-region epithelium lined with cuticle, lying on the collagen layer. Note the free sperm in the lumen. The rectangular area is shown under TEM in panel N. (O) Apex of the ventral epithelium, showing mitochondria and the cuticle. $\mathrm{CL}=$ collagen layer, $\mathrm{CU}=$ cuticle; $\mathrm{DL}=$ dense layer; $\mathrm{DR}=$ dorsal region; $\mathrm{FB}=$ fibroblast, $\mathrm{GC}=$ Golgi complex; $\mathrm{HC}=$ hemocytes; $\mathrm{L}=$ lumen; $\mathrm{MV}=$ microvilli; $\mathrm{MDE}=$ modified epithelium of the dorsal region; $\mathrm{MT}=$ mitochondria; $\mathrm{N}=$ nucleus; $\mathrm{OD}=$ oviduct; $\mathrm{S}=$ secretion; $\mathrm{SP}=$ spermatozoa; $\mathrm{V}=$ vesicles; $\mathrm{VEP}=$ ventral epithelium; $\mathrm{VR}=$ ventral region; $\mathrm{VS}=$ vessel. 


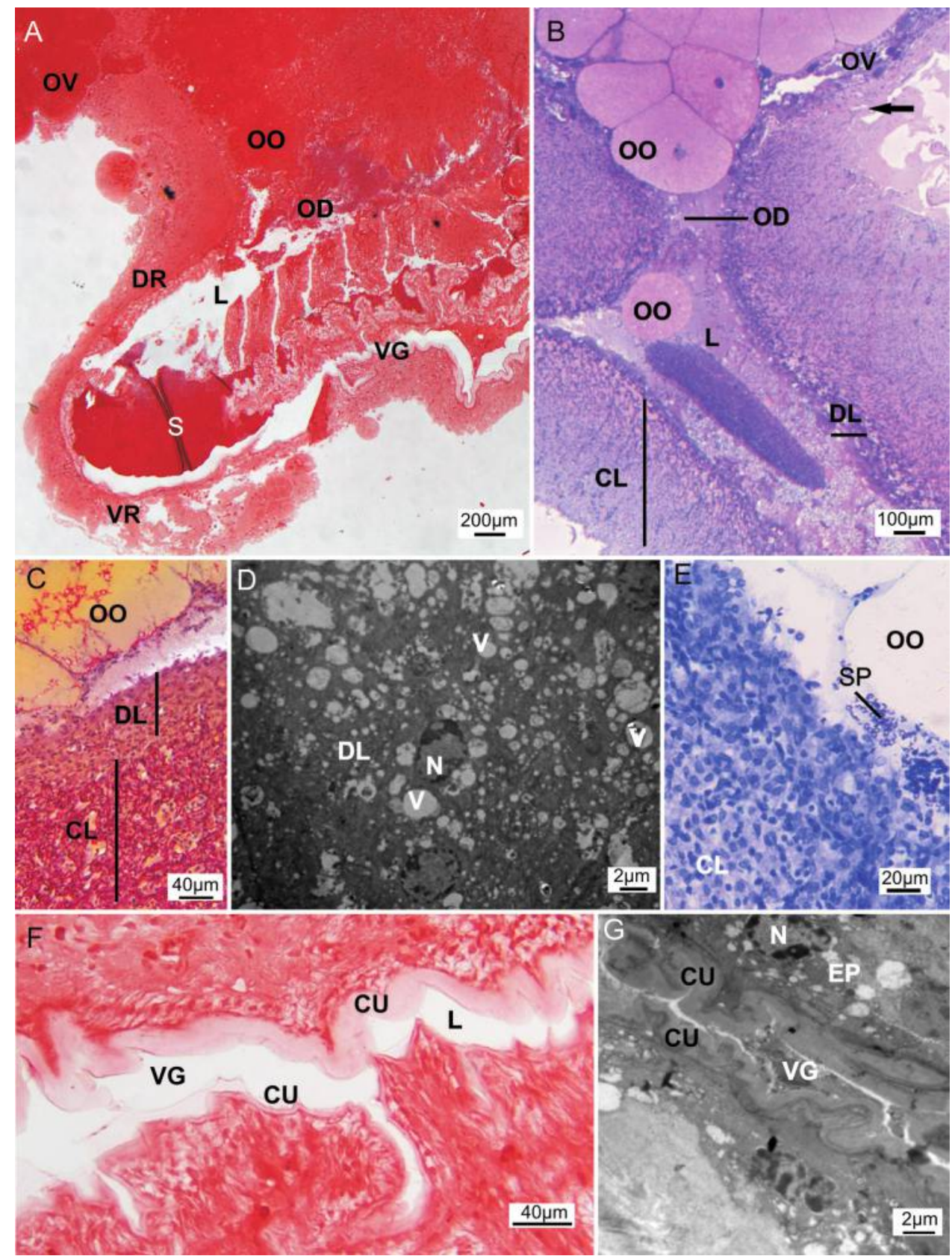

Figure 7. Seminal receptacle (SR) of ovigerous (OV) female during ovulation. (A) View of the SR stained with xylidine ponceau. The ventral region becomes displaced from the central axis. (B) Oocytes in the oviduct continuous with the dorsal region of the SR. Note the transition from ovary to SR (arrow). (C) Aspect of the oviduct-SR, showing thin dense layer and thick collagen layer. (D) Ultrastructure of thin dense layer, showing the cells filled with secretory vesicles. (E) Spermatozoa in the dorsal region of the receptacle, among the oocytes. (F) Vaginal epithelium stained for protein using the xylidine ponceau technique. (G) Ultrastructure of the vagina covered by cuticle. $\mathrm{CL}=$ collagen layer, $\mathrm{CU}=$ cuticle; $\mathrm{DL}=$ dense layer; $\mathrm{DR}=$ dorsal region; $\mathrm{EP}=$ vagina epithelium; $\mathrm{L}=$ lumen; $\mathrm{N}=$ nucleus; $\mathrm{OD}=$ oviduct; $\mathrm{OO}=$ oocyte; $\mathrm{OV}=$ ovary; $\mathrm{S}=$ secretion; $\mathrm{SP}=$ spermatozoa; $\mathrm{V}=$ vesicles; $\mathrm{VG}=$ vagina; $\mathrm{VR}=$ ventral region.

formed with secretions transferred from the male vas deferens to the female SR during mating, as proposed for other species of Portunidae and Cancridae (Edwards, 1966; Ryan, 1967; Jivoff, 1997a ,b; Zara et al., 2012; Nascimento and
Zara, 2013). Although the sperm plug also originates in the rosette glands of gonopods, as proposed by Spalding (1942), in portunids the main component seems to originate from the vas deferens. This is demonstrated by the large amount 
of secretions, which increase as the male matures, as observed for $C$. danae and Callinectes ornatus Ordway, 1863 (Johnson, 1980; Zara et al., 2012; Nascimento and Zara, 2013). Several functions are attributed to the internal sperm plug, including sperm nutrition, a "nuptial gift" to the female, to prevent loss of sperm after mating and to limit the amount of seminal fluid transferred by other males after the first mating (Spalding, 1942; Johnson, 1980: Jivoff, 1997a; Hines et al., 2003; Wolcott et al., 2005; Pardo et al., 2014). In A. cribrarius the dissolution of the sperm plug was associated with desquamation cells producing holocrine secretions. Holocrine secretion in the dorsal region of the SR is common in cancrids (Jensen et al., 1996), majoids (Diesel, 1989; Beninger et al., 1993; Sal Moyano et al., 2010; Gonzales-Pisani et al., 2012), and portunoids (Ryan, 1967; Hartnoll, 1968; Johnson, 1980; Bawab and El-Sherief, 1988). However, apocrine secretion has been described in pea crabs (Pinnotheridae), and it is proposed that this mechanism could be more efficient than holocrine secretion, as supported by the amount of secretion inside the SR (Becker et al., 2011). In the present study we observed only holocrine secretion in all ovarian stages. The peak of holocrine cell activity occurred during the DE stage, marked by folds in the dense layer, numerous large secretory vesicles in the desquamating cells, and sperm plug dissolution. Spalding (1942) proposed that the secretions of the dorsal region of the SR might function as enzymes in dissolving the sperm plug. Krishnakumar (1985 in Adiyodi and Anilkumar, 1988) detected proteases in the SR of Paratelphusa hydrodromous (Herbst), although the origin of these enzymes is uncertain. In addition, Jayasankar and Subramoniam (1997) found protease activity in the seminal fluid of the portunid Scylla serrata (Forskål, 1775). Because of the weak reactivity for proteins and neutral polysaccharides in the desquamation cells of $A$. cribrarius, we speculate that the enzymes that dissolve the sperm plug may originate from the male seminal fluid, as in S. serrata (Jayasankar and Subramoniam, 1997). However, the enzymatic activity occurs only in the presence of the holocrine secretion of the SR. Thus, further studies should be carried out to elucidate the enzyme production in the vas deferens and SR dense layer cells during the sperm plug dissolution.

We observed no phagocytosis or absorption of the sperm plug material in the entire SR, in any stage of ovarian development. The glycoprotein sperm plug in A. cribrarius seems to have no nutritional value for the female or for the stored spermatophores, in agreement with suggestions made for other portunids (Ryan, 1967; Hines et al., 2003; Wolcott et al., 2005). Nevertheless, the final destination of the dissolved sperm plug of A. cribrarius has not been clarified, similarly to P. hawaiiensis and C. sapidus (Ryan, 1967; Johnson, 1980).

In A. cribrarius, at the same time that the sperm plug dissolved, the spermatophore wall disappeared. Thus, the spermatophore dehiscence is associated with the dissolution of the sperm plug. The processes that cause spermatophore dehiscence in the crab SR remain unknown (Beninger $e t$ al., 1993). Adiyodi and Anilkumar (1988) proposed that SR secretions promote this function, most likely through enzymatic activity (Spalding, 1942; Diesel, 1989). Beninger et al. $(1988,1993)$ showed that in Chionoecetes opilio (Fabricius, 1788), spermatophore dehiscence occurs through uptake of water when the spermatophore is exposed to seawater. In A. cribrarius, seawater did not cause dehiscence in the spermatophores removed from the male vas deferens. The rupture of the spermatophore wall occurred only in the presence of the SR secretions during the sperm plug dissolution, in agreement with previous studies (Spalding, 1942; Adiyodi and Anilkumar, 1988; Diesel, 1989).

The dorsal region of the SR of A. cribrarius became continuous with the oviduct in the INT, MAT, and OV ovarian stages, as described for other species of Portunidae with a dorsal-type SR (Ryan, 1967; Johnson, 1980). The dense layer became thinner, although desquamation continued (holocrine secretion). A similar reduction of the dense layer was observed in the portunid $P$. hawaiiensis (Ryan, 1967). In contrast, females of A. cribrarius in the late stages of ovarian development did not show any germinative stratum (mitotic cells) in the dense layer, and the epithelium did not appear to self-renew, differing from hard-female mating species such as C. opilio (Sainte-Marie and Sainte-Marie, 1998), which can receive new sperm from different males at any time. Based on the results of the present study and on the available literature, three possible scenarios can be predicted from this finding: (1) the sperm plug could stimulate the dense layer to restart mitotic activity in hard-female mates of intermolt adult females; (2) an additional molt after puberty might occur, to restore the dense-layer condition, providing an appropriate environment to receive a new sperm plug and spermatophores; and (3) the adult female may extrude successive broods using the genetic material received from the soft-female mating during her life span, without renewing the dense layer. For the first scenario, hard-female mating in A. cribrarius was described in captivity as anomalous short-mating behavior, and the brood produced was lost after a few days (Pinheiro and Fransozo, 1999). In the second scenario, intense mitotic activity was recorded for the dense layer in prepubertal females of blue crabs (Johnson, 1980). However, additional molts in adult females are unusual for blue crabs (Olmi, 1984), and only $1 \%$ of adult females of A. cribrarius are in the premolt stage, indicating that an additional molt occurs (Pinheiro and Fransozo, 1998, 1999, 2002). Thus, the third scenario and, less frequently, the second one might occur in the SR of A. cribrarius.

Sant'Anna et al. (2007) proposed that the secretions of the dorsal region of the SR in Ucides cordatus (Linnaeus, 
1763) contribute to moving the spermatozoa to the fertilization site. In this crab, this movement could also mix the sperm if more than one male copulated with the female. Thus, both points raised for $U$. cordatus also occur in $A$. cribrarius. In addition, the movement of sperm to a moreventral region is also related to the alteration in the SR morphology caused by the sperm plug dissolution. Several authors have proposed that sperm competition occurs in the SR, associated with the position of the sperm packets from different males inside the SR. In some crabs, the position of the sperm packets in the dorsal or ventral opening of the oviducts might favor either the first or the last male to mate (for review see Diesel, 1991; McLay and Lopéz Greco, 2011). This seems not to be the case for A. cribrarius or other blue crabs. In blue crabs, about $12 \%$ of females showed multiple mating, with ejaculate from more than one male present in the SR (Jivoff, 1997a). Jivoff (1997a, b) stated that for large blue crab males, the length of time of the post-copulatory embrace and the amount of ejaculate forming the sperm plug are the keys to sperm competition in blue crabs, suggesting that ejaculate from any of the males can fertilize the eggs. The sperm plug dissolution in $A$. cribrarius accords with the findings of Jivoff (1997a), and we can predict that a multiple-mated female will dissolve both sperm plugs in late stages of the ovarian cycle, and only one mass of sperm will be found in the ventral region of the SR. Thus, sperm from different males can have access to unfertilized eggs, although the proportion of sperm could differ, as demonstrated for blue crabs (Jivoff, 1997a).

Part of the secretion found in the SR during the late ovarian stages seems to be produced by the modified dorsal epithelium and is released by exocytosis between true microvilli. Johnson (1980) raised the possibility that the modified dorsal epithelium could be a ciliated epithelium in $C$. sapidus. These cells in A. cribrarius showed typical microvilli filled with actin filaments. The chemical composition of the secretions produced by modified dorsal epithelium was mainly proteins, together with neutral and acid polysaccharides. These acid polysaccharides were found beginning in the JUV stage and were not present in the sperm plug. Although their function was not clarified in the present study, it is suggested that SR secretions play a role as antimicrobial agents, mainly against bacteria (Johnson, 1980; Beninger et al., 1993; Jensen et al., 1996; Jayasankar and Subramoniam, 1997). In addition, bactericidal and bacteriostatic functions are attributed to acid polysaccharides (Sasikala and Subramoniam, 1987; Beninger et al., 1993; Benhalima and Moriyasu, 2001). In A. cribrarius, the presence of an acid secretion, such as acid polysaccharides, prior to copulation may indicate that the SR is being prepared to receive male seminal fluids. These acid polysaccharides continued to be produced after the spermatophore dehiscence, indicating that the spermatophore wall acts as a protective capsule for the spermatozoa during mating and sperm plug dissolution. In the later stages of ovarian development, a small amount of neutral glycoprotein secretion was found among the spermatozoa. These SR secretions may act as metabolites to maintain the spermatophores and spermatozoa (Johnson, 1980; Beninger et al., 1993; Anilkumar et al., 1996; Sainte-Marie and Sainte-Marie, 1998; Sant'Anna et al., 2007) for long periods (Becker et al., 2011).

During ovulation and egg extrusion in A. cribrarius, more than one oocyte passed through the sperm mass in the ventral region. Although these observations were made from only one female maintained in the laboratory, we observed that the entire dorsal region of the SR was modified in the tube and was continuous with the oviduct. However, we failed to detect a "valve-like tissue" between the SR and the oviduct as described for Eriocheir sinensis H. Milne Edwards, 1854 (Lee and Yamazaki, 1990). According to these authors, this tissue fills the oviduct, preventing early communication with the SR, except during ovulation. If this valve-like tissue occurs in A. cribrarius, it could be located closer to the ovary than the oviduct-SR transition. In A. cribrarius, fertilization can occur in both the dorsal and ventral regions of the SR, similar to that described for the portunid $P$. hawaiiensis (Ryan, 1967, as $P$. sanguinolentus).

The main evolutionary impetus for female mating strategies was derived from the consequences of better sperm conservation and the structure of the seminal receptacle (McLay and López Greco, 2011). Sal Moyano et al. (2012) suggested that in Neohelice granulata (Dana, 1851) females can adjust their period of receptivity and control the time of fertilization, according to different internal mechanisms related to the morphology of the vulvae and the filling of the SR. Thus, the present study revealed that ovarian development, sperm plug dissolution, and spermatophore dehiscence are synchronized. In addition, the holocrine secretion produced by the dense layer appears to be related to both sperm plug dissolution and spermatophore dehiscence, rather than spermatophore dehiscence being related to hydration of the spermatophores, as is observed in majoids. In the late stages of ovarian development (from INT on) the SR becomes flaccid and its morphology is only slightly modified until ovulation.

\section{Acknowledgments}

The authors thank the São Paulo Research Foundation FAPESP (FJZ grants JP \#2005/04707-5 and Biota \#2010/ 50188-8) for financial support, and GRR Pereira for a scholarship (grant IC \#2009/18383-8). We are grateful to the Coordenação de Aperfeiçoamento de Pessoal de Nível Superior CAPES (CIMAR\#23038.004309/2014-51) and Prope-UNESP primeiros projetos. We thank Dr. Janet W. Reid (JWR Associates) for editing the English text. This 
work follows the Brazilian laws (FJZ permanent license MMA-SISBIO \#34587-1).

\section{Literature Cited}

Adiyodi, K. G., and G. Anilkumar. 1988. Arthropoda-Crustacea. Pp. 261-318 in Reproductive Biology of Invertebrates, Vol. 3, Accessory Sex Gland, K. G. Adiyodi and R. G. Adiyodi, eds. John Wiley, Chichester.

Anilkumar, G., K. Sudha, E. Anitha, and T. Subramoniam. 1996. Aspects of sperm metabolism in the spermatheca of the brachyuran crab Metopograpsus messor (Forskal). J. Crust. Biol. 16: 310-314.

Bawab, F. M., and S. S. El-Sherief. 1988. Stages of the reproductive cycle of the female crab Portunus pelagicus (L., 1758) based on the anatomical changes of the spermatheca (Decapoda, Brachyura, Portunidae). Crustaceana 54: 139-148.

Becker, C., D. Bradis, and V. Storch. 2011. Morphology of the female reproductive system of European pea crabs (Crustacea, Decapoda, Brachyura, Pinnotheridae). J. Morphol. 272: 12-26.

Benhalima, K., and M. Moriyasu. 2001. Prevalence of bacteria in the spermathecae of female snow crab, Chionoecetes opilio (Brachyura: Majidae). Hydrobiologia 449: 261-266.

Beninger, P. G., R. W. Elner, T. P. Foyle, and P. H. Odense. 1988. Functional anatomy of the male reproductive system and female spermatheca in the snow crab Chionoecetes opilio (O. Fabricius) (Decapoda: Majidae) and a hypothesis for fertilization. J. Crust. Biol. 8: 322-332.

Beninger, P. G., C. Lanteigne, and N. W. Elner. 1993. Reproductive processes revealed by spermatophore dehiscence experiments and by histology, ultrastructure and histochemistry of the female reproductive system in the snow crab Chionoecetes opilio (O. Fabricius). J. Crust. Biol. 13: 1-16.

Costa, T. M., and M. L. Negreiros-Fransozo. 1998. The reproductive cycle of Callinectes danae Smith, 1869 (Decapoda, Portunidae) in the Ubatuba region, Brazil. Crustaceana 71: 615-627.

Diesel, R. 1989. Structure and function of the reproductive system of the symbiotic spider crab Inachus phalangium (Decapoda: Majidae): observations on sperm transfer, sperm storage and spawning. J. Crust. Biol. 9: 266-277.

Diesel, R. 1991. Sperm competition and the evolution of mating behaviour in Brachyura, with special reference to spider crabs (Decapoda, Majidae). Pp. 145-163 in Crustacean Sexual Biology, R. T. Bauer and J. W. Martin, eds. Columbia University Press, New York.

Edwards, E. 1966. Mating behavior in the European edible crab (Cancer pagurus L.). Crustaceana 10: 23-30.

Gömöri, G. 1939. Silver impregnation of reticulum in paraffin sections. Am. J. Pathol. 13: 993-1001.

González-Pisani, X., P. Barón, and L. S. López Greco. 2012. Functional anatomy of the female reproductive systems of two spider crabs (Decapoda, Majoidea). Invertebr. Biol. 131: 1-74.

Graça-Lopes, R., A. R. G. Tomás, S. L. S. Tutui, E. SeverinoRodrigues, and A. Puzzi. 2002. Fauna acompanhante da pesca camaroeira no litoral do Estado de São Paulo, Brasil. Bol. Inst. Pesca 28: $173-188$.

Guinot, D., and G. Quenette. 2005. The spermatheca in podotreme crabs (Crustacea, Decapoda, Brachyura, Podotremata) and its phylogenetic implications. Zoosystema 27: 267-342.

Guinot, D., M. Tavares, and P. Castro. 2013. Significance of the sexual openings and supplementary structures on the phylogeny of brachyuran crabs (Crustacea, Decapoda, Brachyura), with new nomina for higherranked podotreme taxa. Zootaxa 3665: 1-414.

Hartnoll, R. G. 1968. Morphology of the genital ducts in female crabs. J. Linn. Soc. 47: 279-300.

Hartnoll, R. G. 1969. Mating in Brachyura. Crustaceana 16: 161-181.
Hines, A. H. 1982. Allometric constraints and variables of reproductive effort in brachyuran crabs. Mar. Biol. 69: 309-320.

Hines, A. H., P. R. Jivoff, P. J. Bushmann, J. Van Montfrans, S. A. Reed, D. L. Wolcott, and T. G. Wolcott. 2003. Evidence for sperm limitation in the blue crab, Callinectes sapidus. Bull. Mar. Sci. 72: 287-310.

Hinsch, G. W. 1986. A comparison of sperm morphologies, transfer and sperm mass storage between two species of crab, Ovalipes ocellatus and Libinia emarginata. Int. J. Invertebr. Reprod. Dev. 10: 79-87.

Jayasankar, V., and T. Subramoniam. 1997. Proteolytic activity in the seminal plasma of the mud crab, Scylla serrata (Forskal). Comp. Biochem. Physiol. 116: 347-352.

Jensen, P. C., J. M. Orensanz, and D. A. Armstrong. 1996. Structure of the female reproductive tract in the Dungeness crab (Cancer magister) and implications for the mating system. Biol. Bull. 190: 336-349.

Jivoff, P. 1997a. The relative roles of predation and sperm competition on the duration of the post-copulatory association between the sexes in the blue crab, Callinectes sapidus. Behav. Ecol. Sociobiol. 40: 175185.

Jivoff, P. 1997b. Sexual competition among male blue crab, Callinectes sapidus. Biol. Bull. 193: 368-380.

Johnson, P. T. 1980. Histology of the Blue Crab Callinectes sapidus: A Model for the Decapoda. Praeger, New York.

Junqueira, L. C. U., and L. M. M. S. Junqueira. 1983. Técnicas Básicas de Citologia e Histologia, $1^{\text {st }}$ ed. Santos Press, São Paulo.

Lautenschlager, A., D. Brandis, and V. Storch. 2010. Morphology and function of the reproductive system of representatives of the genus Uca. J. Morphol. 271: 1281-1299.

Lee, T.-H., and F. Yamazaki. 1990. Structure and function of a special tissue in the female genital ducts of the Chinese freshwater crab Eriocheir sinensis. Biol. Bull. 178: 94-100.

López Greco, L. S., G. C. López, and E. M. Rodríguez. 1999. Morphology of spermatheca in the estuarine crab Chasmagnathus granulata Dana 1851 (Grapsidae, Sesarminae). J. Zool. 249: 490-493.

López Greco, L. S., V. Fransozo, M. L. Negreiros-Fransozo, and D. C. Santos. 2009. Comparative morphology of the seminal receptacles of Ocypode quadrata (Fabricius, 1787) (Brachyura, Ocypodoidea). Zootaxa 2106: 41-50.

Mancini, K., and H. Dolder. 2001. Ultrastructure of apyrene and eupyrene spermatozoa from the seminal vesicle of Euptoieta hegesia (Lepidoptera: Nymphalidae). Tissue Cell 33: 301-308.

McLay, C. L., and L. S. López Greco. 2011. A hypothesis about the origin of sperm storage in the Eubrachyura, the effects of seminal receptacle structure on mating strategies and the evolution of crab diversity: How did a race to be first become a race to be last? Zool. Anz. 250: $378-406$.

Mello, M. S. L., and B. C. Vidal. 1980. Práticas de Biologia Celular. Edgar Blucher-FUNCAMP, São Paulo.

Melo, G. A. S. 1996. Manual de identificação dos Brachyura (caranguejos e siris) do litoral brasileiro. Plêiade, São Paulo.

Nascimento, F. A., and F. J. Zara. 2013. Development of the male reproductive system in Callinectes ornatus Ordway, 1863 (Brachyura: Portunidae). Nauplius 21: 161-177.

Olmi, E. J. 1984. An adult female blue crab, Callinectes sapidus Rathbun (Decapoda, Portunidae), in proecdysis. Crustaceana 46: 107-109.

Pardo, L. M., M. Riveros, J. P. Fuentes, and L. López-Greco. 2014. Functional morphology of the seminal receptacle in the crab Metacarcinus edwarsii. Invertebr. Biol. 132: 386-393.

Pearse, A. G. E. 1985. Histochemistry: Theoretical and Applied. Churchill Livingstone, Edinburgh.

Pinheiro, M. A. A., and A. Fransozo. 1998. Sexual maturity of the speckled swimming crab Arenaeus cribrarius (Lamarck, 1818) (Decapoda, Brachyura, Portunidae), in the Ubatuba littoral, São Paulo state, Brazil. Crustaceana 71: 434-452. 
Pinheiro, M. A. A., and A. Fransozo. 1999. Reproductive behavior of the swimming crab Arenaeus cribrarius (Lamarck, 1818) (Crustacea, Brachyura, Portunidae) in captivity. Bull. Mar. Sci. 64: 243-253.

Pinheiro, M. A. A., and A. Fransozo. 2002. Reproduction of the speckled swimming crab Arenaeus cribrarius (Brachyura: Portunidae) on the Brazilian coast near $23^{\circ} 30^{\prime}$ S. J. Crust. Biol. 22: 416-428.

Pyle, R., and L. E. Cronin. 1950. The General Anatomy of the Blue Crab Callinectes sapidus Rathbun. Chesapeake Biological Laboratory Publication No. 87, Maryland Board of Natural Resources, Solomons Island, MD. $40 \mathrm{pp}$.

Rotllant, G., E. González-Gurriarán, L. Fernández, K. Benhalima, and E. Ribes. 2007. Ovarian maturation of the multi-spawning spider crab Maja brachydactyla (Decapoda: Majidae) with special reference to yolk formation. Mar. Biol. 152: 383-394.

Ryan, E. P. 1967. Structure and function of reproductive system of the crab Portunus sanguinolentus (Herbst) (Brachyura: Portunidae). I. The male system. Proc. Symp. Crust. Mar. Biol. Assoc. India Series 2: 506-521.

Saint-Marie, G., and B. Saint-Marie. 1998. Morphology of the spermatheca, oviduct, intermediate chamber and vagina of the adult snow crab (Chionoecetes opilio). Can. J. Zool. 76: 1589-1604.

Sal Moyano, M. P., M. A. Gavio, and E. I. Cuartas. 2010. Morphology and function of the reproductive tract of the spider crab Libinia spinosa (Crustacea, Brachyura, Majoidea): pattern of sperm storage. Helgol. Mar. Res. 64: 213-221.

Sal Moyano, M. P., T. Luppi, M. A. Gavio, M. Vallina, and C. McLay. 2012. Receptivity of female Neohelice granulata (Brachyura, Varunidae): different strategies to maximize their reproductive success in contrasting habitats. Helgol. Mar. Res. 66: 661-667.

Sant'Anna, B. S., M. A. A. Pinheiro, M. Mataqueiro, and F. J. Zara.
2007. Spermathecae of the mangrove crab Ucides cordatus: a histological and histochemical view. J. Mar. Biol. Assoc. UK 87: 903-911.

Sant'Anna, B. S., A. Turra, and F. J. Zara. 2010. Simultaneous activity of male and female gonads in intersex hermit crabs. Aquat. Biol. 10: 201-209.

Sasikala, S. L., and T. Subramoniam. 1987. On the occurrence of acid mucopolysaccharides in the spermatophores of two marine prawns, Penaeus indiens (Milne-Edwards) and Metapenaeus monoceros (Fabricius) (Crustacea: Macrura). J. Exp. Mar. Biol. Ecol. 113: 145-153.

Sokal, R. R., and F. J. Rohlf. 1995. Biometry. W.H. Freeman, New York.

Souza, L. P., J. R. F. Silva, A. M. Araujo, and M. I. Camargo-Mathias. 2013. Morphology of the female genital ducts of the blue land crab Cardisoma guanhumi (Crustacea: Brachyura: Gecarcinidae). Acta Zool. 94: 300-307.

Spalding, J. F. 1942. The nature and formation of the spermatophore and sperm plug in Carcinus maenas. Q. J. Microsc. Sci. 83: 399-423.

Wolcott, D. L., C. W. B. Hopkins, and T. G. Wolcott. 2005. Early events in seminal fluid and sperm storage in the female blue crab Callinectes sapidus Rathbun: effects of male mating history, male size and season. J. Exp. Mar. Biol. Ecol. 319: 43-55.

Zara, F. J., M. H. Toyama, F. H. Caetano, and L. S. López-Greco. 2012. Spermatogenesis, spermatophore, and seminal fluid production in the adult blue crab Callinectes danae (Portunidae). J. Crust. Biol. 32: $249-262$

Zara, F. J., H. H. Gaeta, T. M. Costa, M. H. Toyama, and F. H. Caetano. 2013. The ovarian cycle histochemistry and its relationship with hepatopancreas weight in the blue crab Callinectes danae (Crustacea: Portunidae). Acta Zool. 94: 134-146. 